\title{
PERSENTASE KARKAS DAN MORTALITAS BROILER DAN AYAM KAMPUNG YANG DI BERI LIMBAH AMPAS PATI AREN TIDAK DIFERMENTASI DAN DIFERMENTASI DALAM RANSUM
}

\author{
Percentage of Carcass and Mortality of Broiler and Native Chicken Fed with Unfermented \\ and Fermented Arenga Waste
}

\author{
Aisyah Nurmi, Melia Afnida Santi, Nurainun Harahap, dan Muharram Fajrin Harahap \\ Faculty of Animal Husbandry, Universitas Muhammadiyah Tapanuli Selatan \\ Jl. Rajainal Siregar.Tanggal.Padangsidimpuan.Sumatera Utara. 22743 \\ Email : aisyah.nurmi@um-tapsel.ac.id
}

\begin{abstract}
The objectives of this research were to study the percentage of carcass of broiler and native chicken given arenga waste fermentation by Saccaromyces cerevisiae and to study arenga waste unfermentation in the ration. Sixty of broiler chickens Arbor Acres strain and sixty native chickens were divided into four dietary treatments and three replications (10 birds/replicate). The design of this experiment was completely randomized design factorial $2 \times 2$, with factor $A$ was feeding (A1 : arenga waste unfermented, A2 : arenga waste fermented), and factor $B$ was chicken species (B1:native chickens, B2:broilers). The variables observed were: (1) body weight, (2) carcass, (3) percentage of carcass, and (4) Mortality. The purposes of this study were to look at the effectiveness of rations and species of chicken used for the percentage of carcass and mortality. The results showed that there was no interaction $(P>0.05)$ between the fed arenga waste fermented or unfermented $2.5 \%$ in the ration, and the type of chicken on weight, carcass and carcass percentage, but there was an interaction on mortality $(P<0.01)$. The fed had no significant $(P>0,05)$ effect on weight, carcass, and carcass percentage, but percentage, but significant effect $(P<0.05)$ on mortality. Types of chickens had a significant effect $(P<0.05)$ on weight, carcass, percentage of carcass and mortality. The mortality rate with unfermented arenga waste was high enough, especially in broiler chickens, but it can be tolerated on native chicken and broilers with saccaromyces cerviseae fermented arenga waste.
\end{abstract}

Keywords : arenga waste, fermentation arenga waste, native chickens, broiler

\section{PENDAHULUAN}

Pakan merupakan salah satu penentu keberhasilan peternakan selain bibit yakni komponen terbesar dari biaya produksi adalah pembiayaan pakan sekitar 60 -- $80 \%$. Untuk mengatasi masalah tersebut adalah mencari bahan pakan alternatif yang potensial, mudah diperoleh, ketersediaanya terus-menerus dan hal yang terpenting adalah pakan tersebut memiliki kandungan nutrisi yang baik terhadap produktivitas ternak. Salah satu pakan alternatif yang dapat dimanfaatkan adalah limbah ampas pati aren terfermentasi (Saccharomyces cerevisiae). Pakan tersebut dapat dicampur dalam ransum ternak, yaitu merupakan kumpulan bahan makanan yang layak dimakan oleh ayam dan telah disusun mengikuti aturan tertentu.

Ketersediaan ampas pati aren yang cukup melimpah dan sampai saat ini masih terabaikan mendorong inisiatif untuk digunakan sebagai pakan alternatif. Ampas pati aren merupakan limbah industri pembuatan tepung aren yang mengandung bahan kering 26,47\%, bahan organik $89,67 \%$, protein kasar 3,19\%, lemak kasar $0,13 \%$ dan serat kasar $31,90 \%$. Rendahnya kandungan nutrisi terutama protein kasar merupakan salah satu kendala penggunaan ampas pati aren sebagai bahan pakan (Kusmiyati, 2007). Oleh sebab itu, diperlukan upaya pengayaan nilai nutrisinya, salah satu upaya untuk meningkatkan kandungan nutrisi ampas pati aren adalah dengan cara fermentasi.

Teknologi fermentasi sudah sering dilakukan untuk meningkatkan kandungan zat makanan dan menurunkan kandungan zat antinutrisi. Dalam proses fermentasi substrat yang digunakan harus mengandung unsur karbon (C) dan nitrogen (N) yang dibutuhkan mikroorganisme untuk pertumbuhan. Hasil fermentasi sangat tergantung pada bahan pakan sebagai bahan dasar (substrat), macam mikroba atau inokulum, dan kondisi lingkungan yang sangat mempengaruhi pertumbuhan dan 
metabolisme mikroba tersebut. Penelitian bertujuan untuk mengetahui pengaruh kualitas ampas pati aren yang difermentasi menggunakan Saccharomyces cerevisiae dengan harapan akan diperoleh peningkatan kualitas nilai nutrisinya. Dengan peningkatan nutrisi tersebut juga diharapkan dapat meningkatkan produksi daging pada broiler maupun ayam kampung dan menurunkan tingkat mortalitas.

\section{MATERI DAN METODE}

\section{Materi}

Materi yang digunakan dalam penelitian ini adalah ampas pati aren (Gambar 1) yang diperoleh dari desa Bulu Mario Kecamatan Sipirok Tapanuli Selatan Sumatera Utara, inokulum Saccharomyces cerevisiae yang diperoleh dari ragi tape, objek penelitian adalah broiler dan ayam kampung. Penelitian menggunakan 120 ekor day old chick (DOC) broiler dan ayam kampung.

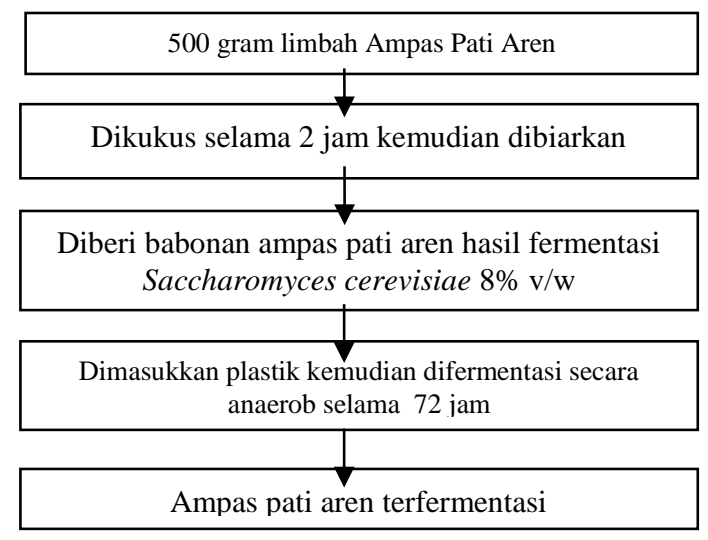

Gambar 1. Diagram alir fermentasi ampas pati aren (Anggraeny, 2009)

\section{Metode}

Manajemen pemeliharaan yang dilakukan pada penelitian ini adalah ayam dipelihara pada 12 kandang individual dengan ukuran $1 \times 2$ meter ditempati 10 ekor ayam tiap kandang. Kandang dilengkapi dengan tempat pakan dan tempat minum. Ayam diberi ransum sesuai perlakuan, selama tujuh minggu masa pemeliharaan dan satu minggu masa adaptasi. Air minum diberikan secara ad libitum selama periode penelitian. Perlengkapan lain yang digunakan antara lain timbangan digital, brooders, pisau, alat bedah dll. Komposisi ransum penelitian dalam bentuk mash disajikan pada Tabel 1.

\section{Rancangan percobaan}

Penelitian ini menggunakan Rancangan Acak Lengkap (RAL) pola faktorial $2 \times 2$, dimana faktor A (A1: Ransum dengan $2.5 \%$ ampas pati aren tanpa fermentasi, A2: Ransum dengan $2.5 \%$ ampas pati aren fermentasi) dan faktor B (B1:ayam kampung, B2: broiler). Data yang diperoleh dianalisis dengan menggunakan analysis of variance (ANOVA). Jika terdapat hasil berbeda nyata maka dilanjutkan dengan uji duncan's multiple range test (DMRT).

Variabel yang diamati adalah:

1. Bobot Akhir (kg) : Bobot akhir didapatkan melalui penimbangan seluruh ayam kemudian dirata-ratakan.

2. Persentase Karkas $(\%)=$

Bobot karkas (gram) x $100 \%$

Bobot Hidup (gram )

3. Mortalitas (\%) : Mortalitas dihitung dengan membandingkan jumlah ayam yang mati selama penelitian dengan jumlah ayam yang dipelihara saat awal penelitian.

Tabel 1. Komposisi ransum penelitian

\begin{tabular}{|c|c|c|}
\hline Komposisi & $\begin{array}{c}\text { Limbah ampas pati aren } \\
\text { tanpa fermentasi (A1) }\end{array}$ & $\begin{array}{c}\text { Limbah ampas pati aren } \\
\text { fermentasi (A2) }\end{array}$ \\
\hline & \multicolumn{2}{|c|}{ 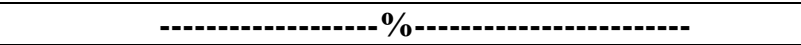 } \\
\hline Jagung & 57 & 57 \\
\hline Dedak & 7.3 & 7.3 \\
\hline Bungkil Kedelai & 24.5 & 24.5 \\
\hline Ampas Pati Aren & 2.5 & 2.5 \\
\hline Tepung Ikan & 6.7 & 6.7 \\
\hline Minyak Nabati & 1 & 1 \\
\hline $\mathrm{DCP}$ & 0.1 & 0.1 \\
\hline $\mathrm{CaCo3}$ & 0.5 & 0.5 \\
\hline Garam & 0.1 & 0.1 \\
\hline Premix & 0.3 & 0.3 \\
\hline \multicolumn{3}{|l|}{ Komposisi Hasil Perhitungan } \\
\hline Energi Metabolisme (kkal/kg) & 2.942 .50 & 2.943 .70 \\
\hline Protein Kasar (\%) & 20 & 20.05 \\
\hline Lemak (\%) & 2.79 & 3.79 \\
\hline Serat Kasar $(\%)$ & 3.90 & 3.79 \\
\hline
\end{tabular}




\section{HASIL DAN PEMBAHASAN}

\section{Bobot Hidup Broiler dan Ayam Kampung}

Pertumbuhan adalah korelasi peningkatan pada tubuh yang tampak pada interval waktu tertentu sesuai dengan karakteristik spesies, sehingga terdapat karakteristik kisaran tubuh untuk setiap spesies dan perkembangan serta ukuran tubuh dewasa. Berdasarkan Tabel 1 hasil penelitian dapat diketahui bahwa bobot hidup broiler berkisar antara $0,989 \mathrm{~kg}$ sampai $1,038 \mathrm{~kg}$. dengan rata-rata bobot hidup $1,013 \mathrm{~kg}$, bobot hidup tertinggi ada pada perlakuan ransum dengan penambahan ampas pati aren terfermentasi sebanyak $2,5 \%$. Sedangkan bobot hidup terendah ada pada perlakuan ransum dengan penambahan ampas sari pati aren tanpa fermentasi.
Berdasarkan Tabel 2 dapat dilihat bahwa bobot hidup ayam kampung berkisar antara 0,325 kg sampai $0,343 \mathrm{~kg}$, dengan rata-rata bobot hidup $0,333 \mathrm{~kg}$. Bobot hidup tertinggi ada pada perlakuan ransum dengan penambahan ampas pati aren tanpa fermentasi berarti pemberian ampas pati aren yang difermentasi memiliki pengaruh yang cukup signifikan terhadap bobot hidup ayam kampung. Hal ini disebabkan limbah ampas pati aren yang difermentasi dapat ditingkatkan kandungan protein kasarnya dibandingkan dengan limbah ampas pati aren yang tidak difermentasi yang tentu saja mengandung serat kasar yang tinggi, sehingga kurang efektif dalam proses pencernaan. Pemilihan proses pengolahan dengan fermentasi yang paling utama untuk mengatasi permasalahan pada tingginya kandungan serat kasar.

Tabel 2. Hasil penelitian bobot hidup persentase karkas dan mortalitas ayam untuk masing-masing perlakuan (gram)

\begin{tabular}{|c|c|c|c|c|}
\hline \multirow[t]{2}{*}{ Parameter } & \multirow{2}{*}{$\begin{array}{c}\text { Jenis } \\
\text { Ransum } \\
\text { (A) }\end{array}$} & \multicolumn{2}{|c|}{ Jenis Ayam (B) } & \multirow[b]{2}{*}{$\begin{array}{c}\text { Rata-rata } \\
\text { A }\end{array}$} \\
\hline & & $\begin{array}{c}\text { Ayam } \\
\text { Kampung } \\
\text { (B1) }\end{array}$ & $\begin{array}{l}\text { Broiler } \\
\text { (B2) }\end{array}$ & \\
\hline Bobot Hidup (kg) & (A1) APA & 0.325 & 0.989 & $0.6570^{\text {tn }}$ \\
\hline Rataan B & (A2) APAF & $\begin{array}{r}0.343 \\
0.334^{\mathrm{a}}\end{array}$ & $\begin{array}{r}1.038 \\
1.013^{\mathrm{b}}\end{array}$ & $0.6906^{\mathrm{tn}}$ \\
\hline Bobot Karkas (kg) & (A1) APA & 0.190 & 0.692 & $0.4410^{\text {tn }}$ \\
\hline Rataan B & (A2) APAF & $\begin{array}{r}0.206 \\
0.198^{\mathrm{a}}\end{array}$ & $\begin{array}{r}0.733 \\
0.713^{\mathrm{b}}\end{array}$ & $0.4695^{\mathrm{tn}}$ \\
\hline Persentase Karkas (\%) & (A1) APA & 58.44 & 70.03 & $64.235^{\text {th }}$ \\
\hline Rataan B & (A2) APAF & $\begin{array}{r}60.02 \\
59.23^{\mathrm{a}}\end{array}$ & $\begin{array}{r}70.76 \\
70.40^{\mathrm{b}}\end{array}$ & $65.390^{\operatorname{tn}}$ \\
\hline Mortalitas (ekor) & $\begin{array}{l}\text { (A1) APA } \\
\text { (A2) APAF }\end{array}$ & $\begin{array}{l}1 \\
1\end{array}$ & $\begin{array}{r}13 \\
1\end{array}$ & $\begin{array}{l}7^{\mathrm{a}} \\
1^{\mathrm{b}}\end{array}$ \\
\hline Rataan B & & $1^{\mathrm{a}}$ & $7^{\mathrm{b}}$ & \\
\hline
\end{tabular}

Keterangan : A1B1: Ampas Pati aren tanpa fermentasi untuk ayam kampung; A1B2: ampas pati aren tanpa fermentasi untuk ayam broiler; A2B1: ampas pati aren fermentasi untuk ayam kampung; A2B2 : ampas pati aren fermentasi untuk ayam broiler. Huruf kecil yang berbeda pada baris dan kolom yang sama menunjukkan pengaruh berbeda nyata $(\mathrm{P}<0.05)$

Hasil analisis ragam menunjukkan bahwa tidak terdapat interaksi $(\mathrm{P}>0,05)$ antara jenis ransum dan jenis ayam. Jenis ayam (ayam kampung dan ayam broiler) berpengaruh nyata $(\mathrm{P}<0,05)$ terhadap bobot hidup, namun jenis ransum (dengan penambahan ampas pati aren tanpa fermentasi) tidak berpengaruh nyata $(\mathrm{P}>0,05)$ terhadap bobot hidup.

\section{Berat Karkas Broiler dan Ayam Kampung}

Berdasarkan Tabel 2 dapat diketahui bahwa berat karkas broiler berkisar antara 0,692 $\mathrm{kg}$ sampai $0,733 \mathrm{~kg}$ dengan rata-rata berat karkas $0,713 \mathrm{~kg}$ berarti penambahan ampas pati aren yang telah difermentasi dalam ransum pakan ternak memiliki dampak positif terhadap berat karkas broiler. Haroen (2003) menjelaskan pencapaian bobot karkas sangat berkaitan dengan bobot hidup dan pertambahan bobot badan. Aviagen (2006) menyatakan bobot karkas broiler berkisar antara 1,750 -- 1,800 $\mathrm{g}$ atau 71--73\% dari bobot badan.

Hasil perlakuan yang diberikan terhadap berat karkas ayam kampung, berkisar antara 0,190 $\mathrm{kg}$ sampai 0,206 kg dengan rata-rata berat karkas $0,198 \mathrm{~kg}$. Berat karkas tertinggi ada pada perlakuan ransum dengan penambahan ampas pati aren terfermentasi sebanyak 2,5\%, sedangkan berat karkas terendah ada pada perlakuan ransum dengan penambahan ampas sari pati aren tanpa fermentasi. Hal ini berarti pemberian ampas sari pati aren yang difermentasi memiliki pengaruh 
yang cukup signifikan terhadap berat karkas ayam kampung. Sehingga direkomendasikan untuk diterapkan bagi peternak ayam kampung untuk mengoptimalkan hasil produksinya dengan memanfaatkan ampas pati aren. Pada penelitian ini dapat terbukti ayam kampung memiliki toleransi yang lebih besar terhadap serat kasar yang dapat dilihat dari rendahnya tingkat kematian.

Hasil analisis ragam menunjukkan bahwa tidak ada interaksi antara jenis ransum yang digunakan dengan jenis ayam $(\mathrm{P}>0,05)$. Jenis ransum yang digunakan berpengaruh tidak nyata terhadap bobot karkas, namun jenis ayam terhadap bobot karkas berbeda sangat nyata $(\mathrm{P}>0,01)$ berarti penambahan ampas pati aren terfermentasi dalam ransum dapat meningkatkan bobot karkas ayam. Rataan tertinggi bobot karkas terdapat pada perlakuan ransum dengan ampas pati aren fermentasi untuk broiler.

\section{Persentase Karkas Broiler dan Ayam Kampung}

Mahfudz (2009) menyatakan bahwa persentase karkas diperoleh dari perbandingan antara bobot karkas terhadap bobot badan akhir dikalikan $100 \%$, berarti persentase karkas sangat bergantung pada tingginya bobot badan akhir ternak ayam sebelum disembelih. Penambahan ampas pati aren terfermentasi sebanyak 2,5\% dalam ransum terhadap persentase karkas ayam broiler memiliki dampak positif yang berujung pada peningkatan persentase karkas ternak atau bahkan juga sebaliknya. Hal ini sesuai dengan pendapat North dan Bell (1992) bahwa persentase karkas broiler bervariasi antara $65-75 \%$ dari bobot badan, semakin berat ayam yang dipotong, maka karkasnya semakin tinggi pula. Persentase karkas broiler berkisar 65,35\% sampai 66,56\% (Daud, 2006).

Hasil penelitian persentase karkas broiler berkisar antara 70,03\% sampai 70,76\%. dengan rata-rata persentase karkas $70,40 \%$. Penambahan ampas pati aren yang telah difermentasi dalam ransum pakan ternak memiliki dampak yang signifikan terhadap pertambahan persentase karkas broiler karena $77,65 \%$ (terfermentasi) lebih besar dibanding 64,79\% (tanpa fermentasi), maka dianjurkan untuk meningkatkan penambahan ampas pati aren terfermentasi agar dapat menambah persentase karkas ayam broiler, dengan harapan dapat mengoptimalkan hasil produksi dari ayam broiler.

Persentase karkas ayam kampung berkisar antara $58,44 \%$ sampai $60,02 \%$. dengan rata-rata persentase karkas $59,23 \%$. Persentase karkas tertinggi pada ayam kampung ada pada perlakuan ransum dengan penambahan ampas sari pati aren terfermentasi sebanyak 2,5\%. Sedangkan persentase karkas terendah ada pada perlakuan ransum dengan penambahan ampas pati aren tanpa berarti penambahan limbah ampas pati aren yang telah difermentasi dalam ransum ternak memiliki dampak yang signifikan terhadap pertambahan persentase karkas ayam kampong, maka dianjurkan untuk melakukan penambahan ampas pati aren terfermentasi agar dapat meningkatkan persentase karkas ayam kampong, sehingga dapat mengoptimalkan hasil produksi dari ayam kampung.

Hasil analis ragam menunjukkan bahwa tidak ada interaksi $(\mathrm{P}>0,05)$ antara jenis ransum yang digunakan (ampas pati aren fermentasi dan tidak difermentasi) dan jenis ayam terhadap persentase karkas. Jenis ransum yang diberikan berpengaruh tidak nyata $(\mathrm{P}>0,05)$ terhadap persentase karkas namun, namun jenis ayam yang digunakan (ayam kampung dan broiler) berpengaruh nyata terhadap persentase karkas $(\mathrm{P}<0.05)$. Hal ini menunjukkan bahwa penambahan ampas pati aren terfermentasi dalam ransum dapat meningkatkan persentase karkas broiler dan ayam kampung.

Pemberian ampas pati aren terfermentasi memberikan pengaruh yang positif terhadap bobot hidup, berat karkas, dan persentase karkas bagi ternak broiler maupun ayam kampong, namun jika dibandingkan pengaruh pemberiannya cenderung lebih tinggi terjadi pada broiler dibanding dengan ayam kampung. Hal ini bisa dilihat dari perbandingan persentase karkas broiler (dengan fermentasi dan tanpa fermentasi), yaitu $75,62 \%>64,79 \%$ atau terjadi peningkatan $10,83 \%$, sedangkan pada perbandingan persentase karkas ayam kampung (dengan fermentasi dan tanpa fermentasi) yaitu $60,73 \%>57.35 \%$ dimana peningkatannya hanya sebesar $3.38 \%$. Secara keseluruhan telah terjadi peningkatan hasil produksi pada ternak broiler maupun ayam kampung, maka terdapat pengaruh yang positif dalam pemanfaatan ampas pati aren terfermentasi terhadap karkas broiler dan ayam kampung dan hipotesis penelitian dapat diterima keberadaannya.

\section{Mortalitas}

Jumlah ayam yang mati selama penelitian disebut mortalitas. Pada tabel dapat dilihat bahwa ayam kampung yang mendapat perlakuan ampas pati aren tanpa fermentasi memiliki daya ketahanan tubuh yang lebih baik jika dibandingkan dengan broiler dengan perlakuan yang sama. Hasil ini tidak jauh berbeda dengan pendapat Scanes et al., (2004) yang menyatakan bahwa tingkat mortalitas broiler pada manajemen pemeliharaan yang baik dapat ditolerir hingga 
3\%. Ini dapat disebabkan karena manajemen peternakan ayam kampung yang dilakukan oleh peternak kecil pada umumnya tidak sebaik pada peternakan ayam broiler komersil, terutama dalam biosecurity.

Menurut Junaedi (2009) mortalitas adalah ukuran jumlah kematian pada suatu populasi. Diperoleh dengan membagi jumlah kematian selama penelitian dengan jumlah populasi selama penelitian dikalikan 100. Pada penelitian ini ayam yang mati (mortalitas) diperiksa oleh dokter hewan, untuk mengetahui penyebab kematian dan dilihat pula hewan yang sakit. Penyebab penyakit pada unggas dapat dibagi menjadi aspek infeksius dan non infeksius. Penyakit infeksius disebabkan adanya agen penyakit yang masuk dan menyerang, sehingga berdampak pada kondisi fisiologis ternak. Penyakit ini dapat disebabkan oleh bakteri, virus, protozoa dan parasit. Penyakit non infeksius disebabkan oleh faktor lain, misalnya kekurangan vitamin, mineral, keracunan atau gangguan hormonal (Trisunuwati et al., 2006).

Mortalitas ayam penelitian ini cukup tinggi pada broiler dengan perlakuan limbah ampas pati aren tanpa fermentasi yaitu 10,83\% (13 ekor dari 120 ekor populasi) dibandingkan dengan ayam kampung dengan perlakuan yang sama yaitu 0,83\% (satu ekor dari 120 ekor populasi). Pada perlakuan limbah ampas pati aren fermentasi, tingkat kematian cukup rendah baik pada broiler maupun ayam kampung. Masing-masing perlakuan hanya satu ekor $(0,83 \%)$. Jika dibandingkan dengan penelitian tentang limbah sagu fermentasi (LSF) yang dilakukan oleh Sinurat (2001) ini sangat rendah (hanya 2 ekor dari 210 ekor atau $0,95 \%$ ) dan tidak ada gejala yang mencurigakan bahwa kematian ayam disebabkan oleh perlakuan. Penelitian terdahulu juga tidak mengindikasikan adanya perbedaan mortalitas karena pemberian LSF (Limbah sagu fermentasi) pada broiler (Sinurat et al., 2000). Hasil ini menguatkan hasil penelitian sebelumnya bahwa penggunaan produk LSF tidak membahayakan kesehatan broiler dan tidak menyebabkan perubahan persentase karkas yang dihasilkan, hati, rempela, maupun lemak abdomen.

Mortalitas broiler dengan perlakuan ransum ampas pati aren tanpa fermentasi $(10,83 \%)$, disebabkan karena ampas pati aren dalam ransum yang digunakan tidak difermentasi sehingga kandungan serat kasar dan lignin yang tinggi pada ampas pati aren menciptakan ketidak seimbangan mikroflora dalam usus.

Penambahan limbah ampas pati aren dalam ransum dan jenis ayam menunjukkan hasil yang berbeda sangat nyata $(\mathrm{P}<0,01)$ terhadap mortalitas. Interaksi antara jenis ayam dan ransum yang digunakan berbeda sangat nyata $(\mathrm{P}<0,01)$ terhadap mortalitas. Mortalitas secara umum dalam penelitian ini 13,3\% (16 ekor mati dari 120 ekor populasi diawal penelitian), di atas ambang normal 5\%. Pemeliharaan broiler dinyatakan berhasil jika angka kematian secara keseluruhan kurang dari 5\%. Angka mortalitas dipengaruhi oleh umur, broiler umur 2-4 minggu memiliki tingkat mortalitas yang lebih tinggi dibandingkan umur 5-8 minggu (Bell dan Weaver, 2002).

Hasil penelitian ini mengindikasikan bahwa pemberian ampas pati aren yang difermentasi dalam ransum memberikan pengaruh positif terhadap penurunan mortalitas ayam kampung dan broiler. Hal ini disebabkan ampas pati aren yang sudah difermentasi dengan mikrobia Saccaromyces cereviceae memiliki dua tipe sistem kerja enzim ekstraseluler: (1) Sistem hidrolitik, yaitu dengan cara menghasilkan enzim hidrolase yang bekerja merombak selulosa dan hemiselulosa dan (2) Sistem oksidatif dan sekresi lignase ekstraseluler dengan cara depolimerisasi lignin (Perez et al., 2002). Keuntungan Saccaromyces cereviceae adalah tidak membunuh mikroba bahkan menambahkan mikroba yang menguntungkan tubuh, sehingga kecernaan pakan akan lebih meningkat (Ahmad, 2006).

Penyebab mortalitas lainnya pada penelitian adalah faktor lingkungan. Faktor-faktor tersebut diantaranya adalah faktor suhu/cuaca pada ayam ketika musim hujan dalam waktu yang lama. Hal ini sejalan dengan pendapat Nova (2008) bahwa lingkungan memberikan pengaruh sebesar $70 \%$ terhadap keberhasilan suatu peternakan. Kondisi cuaca yang tidak normal akan mempengaruhi penurunan konsumsi pakan, penurunan bobot badan dan akhirnya akan menyebabkan kematian. Faktor-faktor yang dapat mempengaruhi mortalitas antara lain bobot badan, bangsa, tipe ayam, iklim, kebersihan lingkungan, sanitasi, peralatan dan kandang serta suhu lingkungan.

Kematian pada broiler terjadi saat periode adaptasi ransum, pada periode awal (starter), sedangkan pada periode finisher sudah jarang. Jika angka kematian naik turun dalam satu periode pencatatan maka, besar kemungkinan adanya kesalahan manajemen yang terjadi (Risa et al., 1999). Sedangkan bila angka itu naik sedikit lalu tetap atau konstan maka kematian dapat disebabkan oleh adanya bakteri atau penyakit lainnya (Fadillah, 2004). 


\section{SIMPULAN DAN SARAN}

\section{Simpulan}

Simpulan penelitian ini yaitu:

1. Tidak ada interaksi antara pemberian limbah ampas pati aren $2,5 \%$ dalam ransum dengan jenis ayam terhadap bobot hidup, bobot karkas, persentase karkas namun ada interaksi terhadap mortalitas.

2. Pemberian limbah ampas pati aren fermentasi dan tanpa fermentasi tidak berpengaruh nyata terhadap bobot hidup, bobot karkas, persentase karkas, namun berpengaruh nyata terhadap mortalitas.

3. Jenis ayam, berpengaruh nyata terhadap bobot hidup, bobot karkas, persentase karkas dan mortalitas.

4. Tingkat kematian dengan ampas pati aren yang tidak difermentasi cukup tinggi, terutama pada broiler, tetapi dapat ditoleransi pada ayam kampung dengan ransum limbah ampas pati aren fermentasi saccaromyces cerviseae.

\section{Saran}

Disarankan kepada peneliti selanjutnya agar menggunakan limbah ampas pati aren terfermentasi dengan level yang lebih tinggi untuk memperoleh hasil yang lebih optimal.

\section{DAFTAR PUSTAKA}

Ahmad, R.Z., 2006. Pemanfaatan Khamir saccaromyces cereviceae untuk ternak. Balitvet. Litbang Pertanian. Bogor.

Anggraeny, Y.N dan U. Umiyasih. 2009. Pengaruh Fermentasi Saccharomyces cerevisiae terhadap Kandugan Nutrisi dan Kecernaan Ampas Pati Aren (Arenga pinnata Merr.). Seminar Nasional Teknologi Peternakan dan Veteriner.

Bell, D. D. and W. D. Weaver Jr. 2002. Commercial Chicken Meat and Egg Production. $5^{\text {th }}$ Ed. Springer Science Business Media Inc. New York.

Daud, M. 2006. Persentase dan Kualitas Karkas Ayam Pedaging yang Diberi Probiotik dan Prebiotik dalam Ransum. Jurnal Ilmu Ternak. Vol. 6 no. 2 :126 -131. Program Studi Ilmu Ternak. Institut Pertanian Bogor. Bogor.

Fadillah. 2004. Panduan Mengelola Peternakan Ayam Broiler Komersial. Cetakan pertama. Agromedia Media Pustaka. Jakarta.

Junaedi, W. 2009. Defenisi Mortalitas. http://wawan-junaedi.blogspot.com .(Diakses tanggal 15 April 2018).
Kusmiyati dan Agustini, N.W.S. 2007. Uji Aktivitas Antibakteri dari Mikroalga Porphyridium cruentum. Biodiversitas 8: 1412-03.

Mahfudz. 2009. Karkas dan Lemak Abdominal Ayam Pedaging yang diberi Ampas Bir dalam Ransum. Prosiding Seminar Nasional Kebangkitan Peternakan. Pusat Penelitian dan Pengembangan Peternakan. Bogor.

North, M.D., and D.D. Bell. 1992. Commercial Chicken Production Manual. Second Edition. The Avi Publishin Co. Inc. Wesport. Conecticut.

Nova K. 2008. Pengaruh Perbedaan Persentase Pemberian Ransum Antara Siang Dan Malam Hari Terhadap Performans Broiler Strain CP 707. J Anim. Sci. 10(2): 117-121.

Perez J., Munoz-Dorado, J., de la Rubia, T. and Martinez, J., 2002. Biodegradation and Biological Treatments of Cellulose, Hemicellulose and Lignin: An Overview. Int. Microbiol. 5: 53-63.

Risa E., R. Semaun dan I. D. Novita. 2014. Evaluasi Penurunan Angka Mortalitas Dan Morbiditas Ayam Pedaging Yang Mendapatan Penambahan Tepung Lempuyang (Zingiber Aromaticum Val) Dalam Ransum. J. Galung Tropika. 3(3): 192-200

Scanes, C.G., G. Brant and M.A. Ensminger. 2004. Poultry Science. $4^{\text {th }}$ Ed. Pearson/Prentice Hall. New Jersey.

Sinurat, A.P., T. Purwadaria, P. Ketaren, D. Zainuddin dan I.P. Kompiang. 2000. Lumpur Sawit Kering Dan Produk Fermentasinya Sebagai Bahan Pakan Ayam Broiler. J. Ilmu Ternak Vet. 5 (2) : 107-112.

Sinurat, A.P., I. A. Bintang, T. Purwadaria, dan T. Pasaribu. 2001. Pemanfaatan Lumpur Sawit dan Produk Fermentasinya Untuk Ransum Unggas. J. Ilmu Ternak Vet. 6(1): 28-33.

Trisunuwati, P.,Indarti R., Masdiana. 2006. Penuntun Praktikum Epidemiologi. Laboratorium Epidemiologi Fakultas Peternakan Universitas Brawijaya. Malang. 